DOI: 10.20884/1.mandala.2018.11.1.535

\title{
CA 125 DAN RISK OF MALIGNANCY INDEX (RMI)2 SEBAGAI PREDIKTOR KEGANASAN TUMOR OVARIUM TIPE EPITEL
}

\section{CA 125 AND RISK OF MALIGNANCY INDEX (RMI)2 AS EPITHELIAL MALIGNANCY OVARIUM PREDICTOR}

\author{
Aditiyono $^{1^{*} \text {, Ali Budi Harsono }}{ }^{2}$, Herman Susanto ${ }^{2}$ \\ ${ }^{I}$ Departemen Obstetri dan Ginekologi, Fakultas Kedokteran, Universitas Jenderal Soedirman, \\ Purwokerto \\ ${ }^{2}$ Departemen Obstetri dan Ginekologi, Fakultas Kedokteran, Universitas Padjajaran, Bandung
}

\begin{abstract}
ABSTRAK
Keganasan ovarium memiliki angka morbiditas dan mortalitas yang tinggi karena umumnya ditemukan pada stadium lanjut. Penelitian ini bertujuan untuk mengetahui spesifitas dan sensitivitas CA 125 dan RMI2 dalam menentukan keganasan kista ovarium jenis epitel. Kadar CA 125 dan RM12 kemudian dilihat histopatologinya sebagai gold standard. Penelitian ini merupakan uji diagnostik, dilakukan di RSUP dr. Hasan Sadikin Bandung periode April s.d. September 2017. Sampel berjumlah 90 dengan 47 berkategori jinak dan 43 berkategori ganas berdasarkan hasil histopatologinya. Analisis data dilakukan secara univariat dan bivariat. Data kategorik diuji dengan uji chi-square atau uji Exact Fisher. Data numerik digunakan uji-t tidak berpasangan atau uji Mann Whitney. Sensitivitas dan spesifisitas data numerik disajikan dalam kurva Receiver Operating Characteristic (ROC). Berdasarkan kurva ROC maka diperoleh nilai area under curve (AUC). Hasil penelitian menunjukkan nilai median CA 125 kelompok ganas dibanding kelompok jinak $(142,2$ vs 61,030) bermakna secara statistik $\mathrm{p}=0,000$ (nilai $\mathrm{p}<0,05)$, cut off point CA 125 adalah $99,9 \mathrm{U} / \mathrm{mL}$ dengan nilai sensitivitas $76,7 \%$ dan nilai spesifisitas $61,7 \%$. Nilai median RMI2 kelompok ganas lebih besar dibandingkan dengan kelompok jinak (1676,8 vs 125) bermakna secara statistik $\mathrm{p}=0,000$ (nilai $\mathrm{p}<0,05$ ), cut off point RMI2 pada penelitian ini adalah 212,7 dengan sensitivitas $86 \%$ dan spesifisitas 70,2\%. Nilai sensitivitas RMI2 dengan cut off point 200 adalah $88 \%$ dan spesifisitas $63,87 \%$. Kesimpulan penelitian ini adalah CA125 adalah biomarker yang berguna untuk memprediksi keganasan ovarium, dengan nilai cut off point 99,9 ng/mL. Hal ini sangat berguna bila digunakan kombinasi CA 125 dengan hasil pemeriksaan Ultrasonografi (USG) dan status menopause atau dikenal dengan Risk Malignancy Index (RMI2 cut off point > 200 ) dengan sensitivitas $86 \%$, spesifisitas $63,87 \%$ dan akurasi $74,4 \%$.
\end{abstract}

Kata Kunci: CA 125, prediktor keganasan, RMI2, tumor ovarium tipe epitel 


\begin{abstract}
The malignancy of ovarian cancer has high level of morbidity and mortality due to the fact that it is commonly found in advanced stage. This research is aimed to find out the specificity and sensitivity of $\mathrm{C} 125$ and RMI2 in determining the malignancy of epithelial ovarian cysts. The level of CA 125 and RM12 is then histopathology-measured as a gold standard. This research is a diagnostic study conducted in Hasan Sadikin Hospital Bandung during April until September 2017. Sample consists of 90 patients with 47 patients belong to low-malignancy group and 43 patients belong to high-malignancy group based on its histopathology. Data analysis is conducted by using univariate and bivariate. Categorical data is tested by using chi-square or Exact Fisher. Numeric data is tested by using unpaired t test or Mann Whitney. Sensitivity and specificity of numeric data is displayed in Receiver Operating Characteristic (ROC) curve. The ROC curve shows the value of area under curve (AUC). The result shows that the median of CA125 of the high-malignancy group compared to the low-malignancy group is $(142,2$ vs 61,030$)$ which statistically means $\mathrm{p}=$ 0,000 (value $\mathrm{p}<0,05$ ), cut off point CA125 is $99,9 \mathrm{U} / \mathrm{mL}$ with sensitivity value $76,7 \%$ and specificity value $61,7 \%$. The median of RMI2 of high-malignancy group is bigger compare to the low-malignancy group (1676,8 vs 125) which statistically means $\mathrm{p}=0,000$ (value $\mathrm{p}<0,05$ ), cut off point RMI 2 of this research is 212,7 with sensitivity value $86 \%$ and specificity value $70,2 \%$. The sensitivity value of RMI 2 with cut off points 200 is $88 \%$ and the specificity value is $63,87 \%$. This research concludes that CA125 is a useful biomarker to predict the malignancy of ovarian cancer with cut off point $99,9 \mathrm{ng} / \mathrm{mL}$. It will be very useful if it is combined with CA125 with Ultrasonography (USG) examination and menopause status or known as Risk Malignancy Index (RMI cut off point $>200$ ) with sensitivity $86 \%$, specificity $63,87 \%$ and accuracy $74,4 \%$.
\end{abstract}

\title{
Keywords: CA125, epithelial ovarian cancer, malignancy predictor, RMI2
}

\footnotetext{
*Corresponding author:
}

Aditiyono

Departemen Obstetri dan Ginekologi, Fakultas Kedokteran, Universitas Jenderal Soedirman,

Purwokerto

Email: draditiyono@gmail.com

\section{PENDAHULUAN}

Keganasan ovarium memiliki angka morbiditas dan mortalitas yang tinggi karena umumnya ditemukan pada stadium lanjut. Hal ini terjadi antara lain oleh sulitnya untuk melakukan deteksi dini dengan tidak munculnya gejala klinik yang dapat dikenali dan rendahnya sensitivitas metode deteksi dini. Menurut data World Health Organization (WHO) 2012 kejadian kanker ovarium pada wanita berada di urutan ke tujuh (Akturk et al., 2011).

Perkembangan lain untuk meningkatkan akurasi diagnostik tumor ganas ovarium adalah penanda tumor. Salah satu penanda tumor yang dapat dipakai sebagai penanda tumor ovarium adalah Cancer antigen 125 (CA 125) yang merupakan glikoprotein dengan berat molekul tinggi dan terletak di permukaan sel, ditemukan pada $80 \%$ keganasan ovarium tipe epitel serosum (Bast $\mathrm{RC}, 2010)$. Penapisan dengan pemeriksaan CA 125 kurang memuaskan karena menunjukkan hasil 
nilai nilai sensitivitas $(84,4 \%)$ dan spesifisitas $(66,3 \%)$ yang rendah (Nakae et al., 2006). CA 125 yang mengikat $E$-cadherin dan kompleks $\beta$-catenin, menghasilkan peningkatan motilitas, migrasi, dan invasi sel yang mengekspresikan CA 125. Seperti dengan beberapa biomarker kanker ovarium lainnya, CA 125 mengekspresikan sel sinyal yang meningkatkan aktivasi reseptor faktor pertumbuhan epidermal (EGFR), yang menghasilkan peningkatan efektor Akt dan ERK1/ 2 dan peningkatkan eksperesi MMP-2 dan MMP-9 (Sarojini et al., 2012). Terdapat peningkatan kadar CA 125 pada 1-2\% individu normal yang sehat, juga pada 5\% pada mereka dengan tumor jinak, dan $28 \%$ meningkat pada penderita tumor ganas non ginekologi sehingga tidak direkomendasikan untuk deteksi dini pasien tanpa gejala (Cohen et al., 2014). False positive pada pemeriksaan CA 125 dapat terjadi pada berbagai kondisi terutama kondisi-kondisi yang berkaitan dengan inflamasi peritoneum.

Risk of malignancy index 2 adalah suatu sistem penilaian atas dasar kombinasi gejala klinis yang dikembangkan untuk meningkatkan keakuratan dalam memperkirakan keganasan suatu tumor ovarium. Hasil perhitungan risk of malignancy index 2 yang lebih besar dari 200 mengindikasikan kemungkinan tumor ovarium ganas (Manegold-Brauer et al., 2016).

Kriteria Risk of Malignancy Index

Temuan Ultrasonografi:

- Kista multilokuler

- Bagian/area padat

- Lesi bilateral

- Ascites

- Metastase intra-abdomen

Score USG :

$0=$ tidak ada temuan abnormal

$1=$ satu temuan abnormal

$4=2$ atau lebih temuan abnormalitas

Status Menopause

$1=$ Premenopause

4 = Postmenopause

\section{CA $125(\mathrm{U} / \mathrm{mL})$}

Nilai RMI2 = ultrasound score $\mathrm{x}$ menopausal status x CA $125^{\text {level }} \mathrm{in} \mathrm{U/mL}$

Dari tabel di atas didapat bahwa risk malignancy index 2 (RMI2) merupakan hasil perkalian antara variabel status menopause, temuan USG, dan kadar serum CA 125. Hasil penilaian RMI2 mengindikasikan suatu keganasan tumor ovarium jika hasil penilaian diperoleh lebih dari 200.

Penanda tumor CA 125 yang diperiksa secara tersendiri sebagai prediksi keganasan ovarium atau digabungkan dengan hasil Ultrasonografi dan status menopause akan meningkatkan akurasi diagnostik prabedah tumor ovarium. Penelitian ini bertujuan mengukur dan membandingkan sensitivitas, spesifisitas, nilai duga positif, nilai duga negatif dan akurasi antara penanda tumor CA 125 dan RMI2 sebagai prediktor keganasan pada penderita tumor ovarium. 


\section{METODE PENELITIAN}

Subjek penelitian adalah pasien dengan kista ovarium yang akan dilakukan operasi di RSUP Dr. Hasan Sadikin Bandung pada periode April-September 2017. Sampel ayng memenuhi kriteria inklusi dan tidak termasuk kriteria eksklusi, serta bersedia mengikuti penelitian dengan menandatangani lembar informed consent. Kriteria Inklusi wanita dengan tumor ovarium dan direncanakan dilakukan operasi, tidak menderita penyakit sumsum tulang maupun penyakit gangguan darah lainnya dan tidak menderita penyakit inflamasi akut. Kriteria eksklusi histopatologi untuk tumor ganas ovarium bukan tipe epitel, memiliki tumor atau kanker lain selain ovarium dan riwayat kemoterapi sebelum operasi.

Penelitian cross sectional atau potong lintang dengan analisis uji diagnostik untuk mengetahui dari parameter (CA 125 dan RMI2) yang dilakukan penelitian, parameter manakah yang lebih sensitif dan spesifik dalam menentukan suatu keganasan pada kista ovarium dari semua subjek penelitian yang memenuhi kriteria penelitian. Besar sampel pada penelitian ini ditentukan dengan rumus besar sampel untuk uji diagnostik berupa nilai sensitivitas, dan spesifisitas bahan pemeriksaan, yaitu: berdasarkan nilai sensitivitas pemeriksaan yang diharapkan berdasarkan penelitian CA 125 sebelumnya sebesar 0,76 (Lan Z, 2016) dengan memilih taraf kepercayaan 95\% dan presisi $10 \%$. Uji statistik untuk membandingkan data numerik dua kelompok dengan uji- $t$ tidak berpasangan apabila data berdistribusi normal, dengan alternatif uji Mann Whitney apabila data tidak berdistribusi normal. Sedangkan Analisis statistik untuk data kategorik diuji dengan uji Chikuadrat apabila syarat Chi-kuadrat terpenuhi. Adapun kriteria kemaknaan yang digunakan adalah nilai $p$ dengan ketentuan apabila $p \leq 0,05$ artinya signifikan. Untuk menggambarkan sensitivitas dan spesifisitas dari data numerik, maka akan disajikan dalam kurva Receiver Operating Characteristic (ROC). Berdasarkan kurva ROC maka diperoleh nilai area under curve (AUC). Data yang diperoleh dicatat dalam formulir khusus kemudian diolah melalui program statistical product and service solution (SPSS) versi 25.0 for windows (Field A, 2013).

\section{HASIL DAN PEMBAHASAN}

Penelitian ini dilakukan pada bulan April 2017 hingga September 2017 pada pasien dengan tumor ovarium yang akan menjalani operasi di RSUP dr. Hasan Sadikin Bandung. Pasien yang berhasil dikumpulkan selama periode penelitian sebanyak 107 orang, yang memenuhi kriteria inklusi dan eksklusi hanya 90 orang, sebanyak 11 orang tidak memenuhi kriteria inklusi karena hasil histopatologinya bukan tipe epitel, yaitu: granulosa sel tumor sebanyak 2 orang, mature cystic teratoma 6 orang, Yolk sac tumor, fibroma dan immature teratoma sebanyak masing-masing 1 orang; 2 abses tubo ovarial dan 4 sampel lisis. Pada hasil pemeriksaan histopatologi jinak terdapat 14 dengan endometriosis

Pada tabel I karakteristik subjek penelitian berdasarkan usia, status menopause, BMI dan leukosit pada kelompok ganas dan jinak. Untuk usia pada kelompok ganas memiliki rata-rata sebesar 45,72 $\pm 13,266$ sedangkan untuk usia pada kelompok jinak memiliki rata-rata sebesar $39,51 \pm 14,103$. Untuk pasien dengan status tidak menopause pada kelompok ganas sebanyak 22 atau sebesar $51,2 \%$ dan pasien yang menopause sebanyak 21 atau sebesar $17,2 \%$ sedangkan untuk pasien dengan status tidak menopause pada kelompok jinak sebanyak 32 atau sebesar $68,1 \%$ dan pasien yang menopause sebanyak 15 atau sebesar 31,9\%. Untuk BMI pada kelompok ganas memiliki median 20,4 sedangkan untuk BMI pada kelompok jinak memiliki median sebesar 23,6. 
Untuk leukosit pada kelompok ganas memiliki median sebesar 7800 sedangkan untuk leukosit pada kelompok jinak memiliki median sebesar 7300.

Untuk analisis usia diuji dengan menggunakan uji- $t$ tidak berpasangan data berdistribusi normal, serta alternatif uji Mann Whitney pada data tidak berdistribusi normal yaitu BMI dan leukosit. Hasil uji statistik pada kelompok penelitian di atas diperoleh informasi nilai p pada variabel leukosit lebih besar dari 0,05 (nilai p>0,05). Nilai p pada variabel umur dan BMI lebih kecil dari 0,05 (nilai $\mathrm{p}<0,05$ ). Untuk analisis status menopause pada tabel di atas diuji dengan menggunakan uji statistika Chi-Square, nilai p pada variabel status menopause lebih besar dari 0,05 (nilai $\mathrm{p}>0,05$ ).

Untuk CA 125 pada kelompok ganas memiliki median 142,2, sedangkan untuk CA 125 pada kelompok jinak memiliki median 61,030. Untuk analisis data numerik ini diuji dengan uji Mann Whitney karena data tidak berdistribusi normal CA 125. Hasil uji statistik pada kelompok penelitian di atas diperoleh informasi nilai p pada variabel CA 125 lebih kecil dari 0.05 (nilai $\mathrm{p}<0,05)$ yang berarti signifikan atau bermakna secara statistik dengan demikian dapat dijelaskan bahwa terdapat perbedaan yang signifikan secara statistik antara variabel CA 125 pada kelompok ganas dan kelompok jinak. Dari hasil analisis perbandingan karakteristik kedua kelompok di atas, maka dapat disimpulkan kedua kelompok berbeda atau ada perbedaan karakteristik.

Tabel I. Karakteristik Subjek Penelitian

\begin{tabular}{|c|c|c|c|}
\hline \multirow[t]{2}{*}{ Variabel } & \multicolumn{2}{|l|}{ Kelompok } & \multirow[t]{2}{*}{ nilai $p$} \\
\hline & $\begin{array}{l}\text { Ganas } \\
\mathrm{N}=43\end{array}$ & $\begin{array}{l}\text { Jinak } \\
\mathrm{N}=47\end{array}$ & \\
\hline Usia (tahun) & & & $0,035^{*}$ \\
\hline Mean \pm Std & $45,72 \pm 13.266$ & $39,51 \pm 14,103$ & \\
\hline Menopause & & & 0,102 \\
\hline Tidak & $22(51,2 \%)$ & $32(68,1 \%)$ & \\
\hline $\mathrm{Ya}$ & $21(17,2 \%)$ & $15(31,9 \%)$ & \\
\hline BMI & & & $0,000 *$ \\
\hline Median & 20,4 & 23,6 & \\
\hline Range (min-max) & $14,60-34,00$ & $17,10-31,20$ & \\
\hline Leukosit & & & 0,205 \\
\hline Median & 7800 & 7300 & \\
\hline Range (min-max) & $4300-13800$ & $2560-16000$ & \\
\hline CA 125 & & & $0,000 *$ \\
\hline Median & 142,20 & 61,03 & \\
\hline Range (min-max) & $16,80-9934,00$ & $7,91-4747,0$ & \\
\hline
\end{tabular}

Keterangan : Untuk data numerik nilai p diuji dengan uji t tidak berpasangan apabila data berdsitribusi normal dengan alternatif uji Mann Whitney pada data tidak berdistribusi normal. Untuk Data kategorik nilai p dihitung berdasarkan uji Chi-Square dengan alternatif uji Kolmogorov Smirnov dan Exact Fisher apabila syarat dari Chi-Square tidak 
terpenuhi. Nilai kemaknaan berdasarkan nilai $\mathrm{p}<0,05$.Tanda* menunjukkan nilai $\mathrm{p}<0,05$ artinya signifkan atau bermakna secara statistik.

Tabel II perbandingan karakteristik subjek penelitian berdasarkan hispatologi pada pasien tumor ovarium ganas dan jinak. Untuk histopatologi Serous carcinoma dan Endometrioid carcinoma 10 atau sebesar 23,3\%, mucinous carcinoma sebanyak 6 atau sebesar 14,0\%. Borderline serous sebanyak 5 atau sebesar 11,6\% dan Borderline mucinous sebanyak 8 atau sebesar 18,6\% sedangkan untuk histopatologi dengan hasil serous kistadenoma sebanyak 13 atau sebesar 27,7\%, Mucinous kistadenoma sebanyak 20 atau sebesar 42,6\%, endometriosis sebanyak 14 atau sebesar $29,8 \%$.

Tabel II. Hispatologi pada pasien tumor ovarium ganas dan jinak

\begin{tabular}{|c|c|c|c|}
\hline \multicolumn{4}{|c|}{ Kelompok } \\
\hline & $\begin{array}{r}\text { ganas } \\
\mathrm{N}=43 \\
\end{array}$ & & $\begin{array}{l}\text { jinak } \\
\mathbf{N}=47\end{array}$ \\
\hline hispatologi & & histopatologi & \\
\hline Serous carcinoma & $10(23,3 \%)$ & Serous kistadenoma & $13(27,7 \%)$ \\
\hline Mucinous carcinoma & $6(14,0 \%)$ & Mucinous kistadenoma & $20(42,6 \%)$ \\
\hline Endometrioid carcinoma & $10(23,3 \%)$ & Endometriosis & $14(29,8 \%)$ \\
\hline Clear Cell carcinoma & $3(7,0 \%)$ & & \\
\hline Seromuscinous carcinoma & $1(2,3 \%)$ & & \\
\hline Borderline serous tumor & $5(11,6 \%)$ & & \\
\hline Borderline mucinous tumor & $8(18,6 \%)$ & & \\
\hline
\end{tabular}

Tabel III. Perbandingan proporsi dan hubungan antara CA 125 dan kategori CA 125 pada kelompok ganas dan jinak

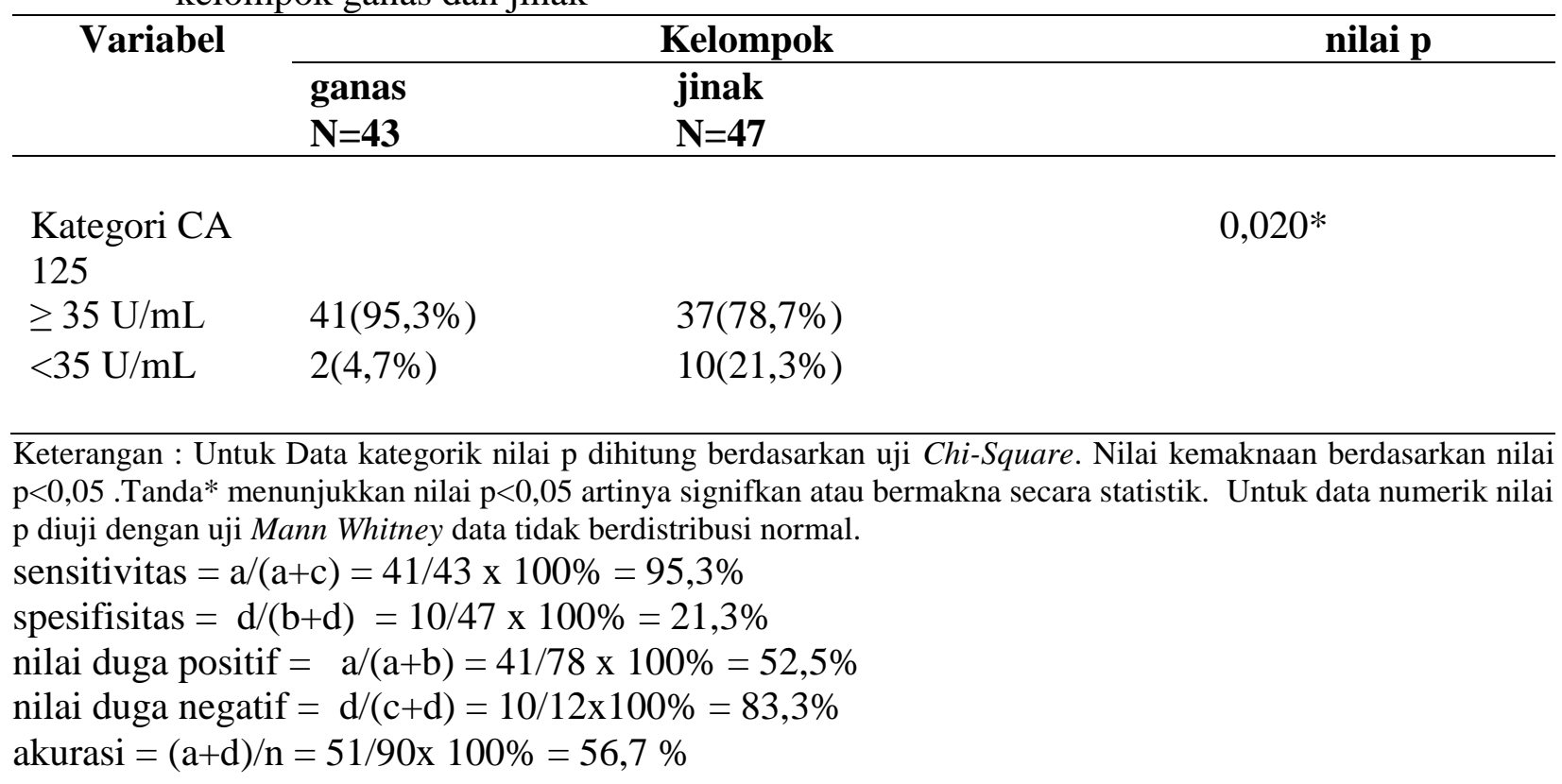


Tabel III menjelaskan perbandingan kategori CA 125 pada kelompok ganas dan jinak. Untuk kategori CA $125<35 \mathrm{U} / \mathrm{mL}$ pada kelompok ganas sebanyak 2 atau sebesar 4,7\% dan $\geq 35$ $\mathrm{U} / \mathrm{mL}$ sebanyak 41 atau sebesar 95,3\% sedangkan untuk kategori CA $125<35 \mathrm{U} / \mathrm{mL}$ pada kelompok jinak sebanyak 10 atau sebesar $21,3 \%$ dan $\geq 35 \mathrm{U} / \mathrm{mL}$ sebanyak 37 atau sebesar 78,7\%. Untuk analisis pada data kategorik yaitu kategori CA 125 pada tabel di atas diuji dengan menggunakan uji statistika Chi-Square, nilai p lebih kecil dari 0,05 (nilai p<0,05).

Tabel IV menjelaskan perbandingan antara cut off CA 125 pada kelompok ganas dan jinak. Untuk cut off CA $125 \geq 99,9 \mathrm{U} / \mathrm{mL}$ pada kelompok ganas sebanyak 33 atau sebesar 76,7\% dan cut off CA $125<99,9 \mathrm{U} / \mathrm{mL}$ sebanyak 10 atau sebesar $23,3 \%$ sedangkan untuk cut off CA $125 \geq$ 99,9 U/mL pada kelompok jinak sebanyak 18 atau sebesar 38,3\% dan cut off CA $125<99,9 \mathrm{U} / \mathrm{mL}$ sebanyak 29 atau sebesar 61,7\%. Untuk analisis pada data kategorik yaitu cut off CA 125 pada tabel diatas diuji dengan menggunakan uji statistika Chi-Square, nilai p pada variabel cut off CA 125 nilai $\mathrm{P}<0,05$ yang berarti signifikan.

Tabel IV. Perbandingan proporsi dan hubungan antara cut off CA 125 pada kelompok ganas dan jinak

\begin{tabular}{llll}
\hline \multirow{2}{*}{ Variabel } & \multicolumn{2}{l}{ Kelompok } & \multirow{2}{*}{ Nilai p } \\
\cline { 2 - 3 } & $\begin{array}{l}\text { ganas } \\
\mathbf{N = 4 3}\end{array}$ & $\begin{array}{l}\text { Jinak } \\
\mathbf{N = 4 7}\end{array}$ & \\
\hline CA 125 cut off & & & $0,000^{*}$ \\
$\geq 99,9 \mathrm{U} / \mathrm{mL}$ & $33(76,7 \%)$ & $18(38,3 \%)$ & \\
$<99,9 \mathrm{U} / \mathrm{mL}$ & $10(23,3 \%)$ & $29(61,7 \%)$ &
\end{tabular}

Keterangan : Data kategorik nilai p dihitung berdasarkan uji Chi-Square. Nilai kemaknaan berdasarkan nilai p $<0,05$ .Tanda* menunjukkan nilai $\mathrm{p}<0,05$ artinya signifkan atau bermakna secara statistik.

Sensitivitas $=\mathrm{a} /(\mathrm{a}+\mathrm{c})=33 / 43 \times 100 \%=76,7 \%$

Spesifisitas $=d /(b+d)=29 / 47 \times 100 \%=61,7 \%$

Nilai duga positif $=\mathrm{a} /(\mathrm{a}+\mathrm{b})=33 / 51 \times 100 \%=64,7 \%$

Nilai Duga Negatif $=\mathrm{d} /(\mathrm{c}+\mathrm{d})=29 / 39 \times 100 \%=74,3 \%$

Akurasi $=(\mathrm{a}+\mathrm{d}) / \mathrm{N}=62 / 90 \times 100 \%=68,8 \%$

Berdasarkan perhitungan yang dilakukan, cut off point CA 125 pada penelitian ini adalah 99,9 U/mL dengan nilai sensitivitas $76,7 \%$ dan nilai spesifisitas $61,7 \%$. Hal ini berarti bahwa 77,5\% pasien dengan CA $125>99,9 \mathrm{U} / \mathrm{mL}$ diprediksi akan mengalami tumor ovarium ganas. Berdasarkan perhitungan di atas maka sensitifitas memiliki nilai hampir sama dengan spesifisitas sehingga dapat disimpulkan bahwa sensitivitas dan spesifitas menghasilkan nilai kecermatan positif yang berbeda dengan nilai kecermatan negatif.

Kurva ROC (receiver operating characteristic) menunjukkan bahwa CA 125 mempunyai nilai diagnostik yang baik karena kurva menjauh dari garis 50\% dan mendekati $100 \%$. Nilai AUC (area under the curve) yang diperoleh dari metode ROC adalah sebesar 77,5\% dengan nilai $\mathrm{p}$ sebesar 0,000 (gambar 1A). AUC 77,5\% artinya CA 125 dapat digunakan untuk memprediksi keganasan tumor ovarium secara tepat pada 72 pasien dari total 90 pasien. 
Berdasarkan interval kepercayaan, nilai CA 125 berada pada level 67,9\% sampai 87,1\%. Uji hipotesis yang didapat dari output SPSS membandingkan AUC yang diperoleh indeks dibandingkan dengan nilai AUC 50\%. Nilai $p<0,05$ yang diperoleh pada output SPSS di atas berarti bahwa CA 125 bermakna secara statistik.

Tabel V. Perbandingan Proporsi dan hubungan antara RMI2 $\geq 200$ pada kelompok Ganas dan Jinak

\begin{tabular}{|c|c|c|c|}
\hline \multirow[b]{2}{*}{ Variabel } & \multicolumn{2}{|l|}{ Kelompok } & \multirow[b]{2}{*}{ Nilai P } \\
\hline & $\begin{array}{l}\text { Ganas } \\
\mathrm{N}=43\end{array}$ & $\begin{array}{l}\text { Jinak } \\
N=47\end{array}$ & \\
\hline RMI2 & & & $0,000 * *$ \\
\hline $\begin{array}{l}\geq 200 \\
<200\end{array}$ & $\begin{array}{l}37(86,0 \%) \\
6(14,0 \%)\end{array}$ & $\begin{array}{l}17(36,2 \%) \\
30(63,8 \%)\end{array}$ & \\
\hline Median & 1676,80 & 125,00 & \\
\hline
\end{tabular}

Keterangan : Untuk Data kategorik nilai p dihitung berdasarkan uji Chi-Square. Nilai kemaknaan berdasarkan nilai $\mathrm{p}<0,05$. Tanda* menunjukkan nilai $\mathrm{p}<0,05$ artinya signifkan atau bermakna secara statistik.

Sensitivitas $=\mathrm{a} /(\mathrm{a}+\mathrm{c})=37 / 43 \times 100 \%=86.0 \%$

Spesifisitas $=\mathrm{d} /(\mathrm{b}+\mathrm{d})=30 / 47 \times 100 \%=63,8 \%$

Nilai duga positif $=a /(a+b)=37 / 54 \times 100 \%=68,5 \%$

Nilai Duga Negatif $=\mathrm{d} /(\mathrm{c}+\mathrm{d})=30 / 36 \times 100 \%=83,3 \%$

Akurasi $=(\mathrm{a}+\mathrm{d}) / \mathrm{N}=70 / 90 \mathrm{x} 100 \%=74,4 \%$

Tabel V menjelaskan perbandingan antara RMI2 dan Kategori RMI2 pada kelompok Ganas dan Jinak. Untuk Kategori RMI2 <200 pada kelompok ganas sebanyak 6 atau sebesar 14\% dan $\geq$ 200 sebanyak 37 atau sebesar 86\% sedangkan Untuk Kategori RMI2 <200 pada kelompok jinak sebanyak 30 atau sebesar $63.8 \%$ dan $\geq 200$ sebanyak 17 atau sebesar $36.2 \%$.

Kurva ROC menunjukkan bahwa RMI2 mempunyai nilai diagnostik yang baik karena kurva menjauh dari garis 50\% dan mendekati 100\% (gambar 1B). Nilai AUC (area under the curve) yang diperoleh dari metode ROC adalah sebesar $88.2 \%$ dengan nilai p sebesar 0.000 , artinya adalah signifikan.

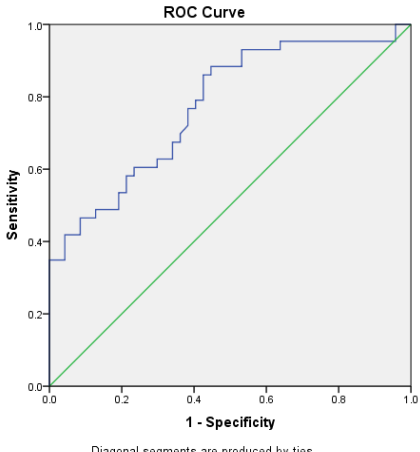

A

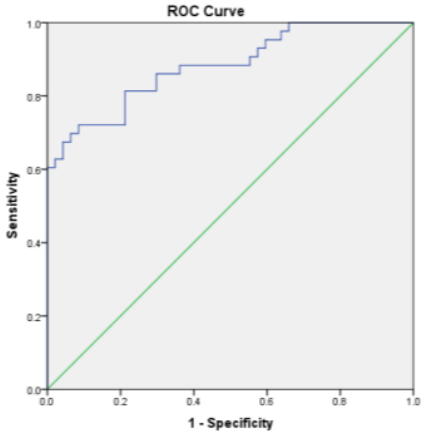

B 


\section{Gambar 1. ROC CA125 (A) dan RMI2 (B) serta keganasan tumor ovarium.}

Tabel VI. Perbandingan Proporsi atau Hubungan antara Cut Off RMI2 pada kelompok Ganas dan Jinak

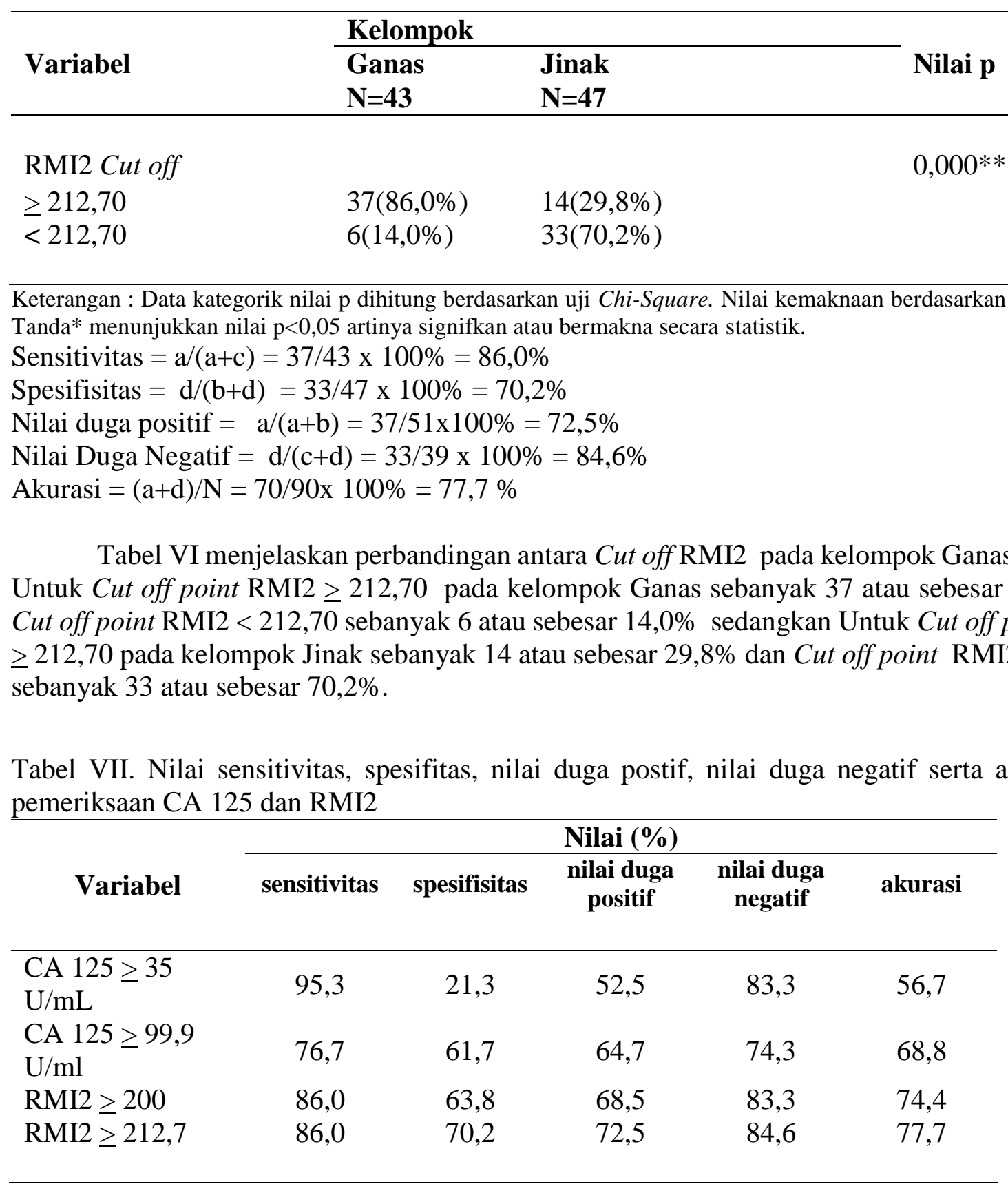

Pada Tabel I perbandingan karakteristik subjek penelitian berdasarkan usia, status menopause pada kelompok ganas dan jinak. Untuk usia pada kelompok ganas memiliki rata-rata 
sebesar 45,72 $\pm 13,266$ sedangkan untuk usia pada kelompok Jinak memiliki rata-rata sebesar $39,51 \pm 14,103$. Untuk pasien dengan status tidak menopause pada kelompok ganas sebanyak 22 atau sebesar 51,2\% dan pasien yang menopause sebanyak 21 atau sebesar 17,2\% sedangkan Untuk pasien dengan status tidak menopause pada kelompok jinak sebanyak 32 atau sebesar $68,1 \%$ dan pasien yang menopause sebanyak 15 atau sebesar 31,9\%. SEER melaporkan bahwa antara tahun 2007-2011 proporsi karsinoma ovarium lebih banyak terjadi pada umur >50 (post-menopause) tahun sebesar 69,3\% dengan frekuensi paling tinggi didapatkan antara umur 55 sampai dengan 64 tahun dengan median umur 63 tahun. Cannistra melaporkan median umur pada negara berkembang 60 tahun dengan risiko 1 dari 70 wanita, risiko ini meningkat sejalan dengan makin lanjutnya umur sampai lebih dari 80 tahun dan kejadian keganasan ovarium tertinggi pada umur 60-65 tahun. Ketika keluhan klinis timbul maka pasien telah berada dalam stadium lanjut sehingga pada penelitian ini lebih dari dua pertiga kasus kasus keganasan ovarium didiagnosis ketika penyakit itu telah berkembang ke tahap III atau IV dan melibatkan rongga peritoneal atau organ lainnya (Howlader et al., 2014 ; Siegel et al., 2014)

Kadar leukosit pada kedua kelompok tidak ada perbedaan bermakna antara kedua kelompok ganas dan jinak. Pada penelitian ini apabila terdapat tanda infeksi pasien diekslusikan. Untuk BMI pada kelompok ganas memiliki median 20,4, sedangkan untuk BMI pada kelompok jinak memiliki median 23,6, sesuai dengan penelitian Erondu yang melaporkan bahwa BMI berhubungan dengan gejala dan tanda dari keganasan ovarium, pada pasien dengan BMI lebih besar keluhan pada keganasan ovarium tidak tampak jelas, sehingga pasien cenderung datang dalam keadaan terlambat. Pasien dengan kanker agresif akan menunjukkan gejala lebih cepat dan mengalami penurunan fisik yang lebih cepat, sehingga menyebabkan mereka untuk segera melakukan perawatan medis (Erondu et al., 2016).

Pada saat ini merupakan satu-satunya penanda tumor yang telah terbukti untuk mendeteksi keganasan ovarium sebelum onset gejala klinis dan secara luas digunakan dalam praktek adalah CA 125. CA 125 dilaporkan memiliki satu sensitivitas tertinggi dan spesifisitas antara penanda tumor untuk keganasan ovarium. Nakae dkk menunjukkan bahwa di antara 32 pasien dengan keganasan ovarium, 34 pasien dengan ovarium jinak tumor, dan 31 wanita sehat, CA 125 memiliki sensitivitas $84,4 \%$ dan spesifitas $66,3 \%$ dalam memprediksi penyakit ini. Meskipun banyak manfaat yang menyertai penggunaan CA 125, banyak tantangan yang membuatnya tidak efektif pada tahap deteksi dini (Rein et al.,2011).

Pada penelitian ini didapatkan CA 125 pada kelompok ganas memiliki median 142,2 U/mL sedangkan untuk CA 125 pada kelompok jinak memiliki median 61,03. Hasil uji statistik pada kelompok penelitian di atas diperoleh informasi nilai p pada variabel kategori CA 125 lebih kecil dari 0,05 (nilai $\mathrm{p}<0,05$ ) yang berarti signifikan atau bermakna secara statistik dengan demikian dapat dijelaskan bahwa terdapat perbedaan persentase yang signifikan secara statistik antara variabel kategori CA 125 pada kelompok ganas dan kelompok jinak.

Pemeriksaan pada penelitian ini dengan cut off point CA $125 \geq 35 \mathrm{U} / \mathrm{mL}$ memiliki sensitivitas $95,3 \%$, spesifisitas $21,2 \%$, nilai duga positif $52,5 \%$ nilai duga negatif $83,3 \%$, serta akurasi 56,7 \%, penelitian ini mungkin dapat dijelaskan pada penelitian oleh Skates dkk dimana batas (cut-off points) CA 125 yang dipakai saat ini yaitu $35 \mathrm{U} / \mathrm{mL}$ pada wanita yang menjalani deteksi dini tumor ganas ovarium perlu dipertimbangkan kembali dengan cara ikut melibatkan faktor-faktor antara lain kelompok pre-menopause, post-menopause dan sub-kelompok tertentu. Pada penelitian ini sensitivitas CA 125 dengan nilai cut off $\geq 99,9 \mathrm{U} / \mathrm{mL}$, adalah 76,7\% dan spesifisitas $74,3 \%$. Skates dkk mendapatkan perbedaan yang bermakna kadar CA 125 pada kelompok wanita post-menopause dibandingkan dengan wanita pre-menopause sebagai kelompok 
kontrol, dimana pada kelompok post-menopause kadar CA 125 lebih tinggi dengan batas 52 U/mL dibandingkan wanita premenopause yang memiliki kadar CA 125 dengan batas $35 \mathrm{U} / \mathrm{mL}$. Begitu juga bila dibandingkan dengan wanita pre-menopause yang menggunakan kontrasepsi oral dimana batas kadar CA 125 adalah $40 \mathrm{U} / \mathrm{mL} .{ }^{17}$ Kadar CA 125 yang tidak bermakna juga seperti yang didapatkan oleh Bast dkk dimana didapatkan hasil 99\% wanita sehat memiliki kadar serum CA 125 dibawah $35 \mathrm{U} / \mathrm{mL}$, sedangkan $82 \%$ wanita dengan tumor ganas ovarium tipe epitel memiliki kadar serum CA 125 di atas $35 \mathrm{U} / \mathrm{mL}$. Pada 90\% kasus tumor ganas ovarium, kadar serum CA 125 berhubungan dengan volume tumor, bukan luas penyakit. Sebagai contoh kadar serum CA 125 pasien tumor ganas ovarium stadium IA dengan tumor berukuran $15 \mathrm{~cm}$ akan lebih tinggi bila dibandingkan dengan tumor ganas stadium IIB yang hanya berukuran $5 \mathrm{~cm}$ (Skates, 2011). Pada penelitian ini $\mathrm{CA} 125 \geq 35 \mathrm{U} / \mathrm{mL}$ memiliki senstivitas tertinggi apabila dibandingkan dengan pemeriksaan RMI2 yaitu sebesar 95,3\%, yang menunjukkan bahwa pemeriksaan CA 125 merupakan sebagai gold standard upaya deteksi dini (McIntosh, 2004).

Banyak penelitian menunjukkan bahwa RMI adalah metode sederhana dan efektif untuk membedakan massa ovarium jinak dari ganas, telah digunakan secara luas untuk membantu dokter dalam pengelolaan kasus yang ditemui sehari-hari (Ong et al., 2016). Modifikasi terakhir (RMI 4) diperkenalkan pada tahun 2009 oleh Yamamoto dkk, yang menambahkan ukuran tumor dalam perhitungan (Yamamoto et al., 2009). Akturk dkk dalam suatu studi prospektif yang mengeluasi 100 wanita untuk memperoleh dan membandingkan sensitivitas, spesifisitas, PPV, NPV dan akurasi diagnostik empat RMI (RMI 1, RMI 2, RMI 3, dan RMI 4)

\section{KESIMPULAN}

Dapat disimpulkan bahwa bahwa tidak ada perbedaan statistik yang signifikan dalam kinerja dan merupakan teknik sederhana dengan sensitivitas dan spesifisitas yang tinggi (sensitivitas $81 \%$ dan spesifisitas $85 \%$, dengan nilai prediksi positif dan negatif masing-masing 48\% dan 96\%) yang dapat digunakan bahkan di klinik ginekologi umum untuk memfasilitasi pemilihan kasus rujukan ke unit onkologi untuk terapi yang optimal (Akturk et al., 2011 ;. van den Akker et al.,2010). Pada penelitian ini RMI2 dengan nilai cut off $\geq 200$ mempunyai nilai sensitivitas $86 \%$, spesifisitas $63,8 \%$ dan akurasi $74,4 \%$.

\section{UCAPAN TERIMA KASIH}

Terima kasih kepada RSUP dr. Hasan Sadikin Bandung yang telah memberikan kesempatan kepada penulis mengambil sampel penelitian.

\section{DAFTAR PUSTAKA}

Akturk, E., Karaca, R.E., Alanbay, I., Dede, M., Karasahin, E., Yenen, M.C., et al. 2011. Comparison of four malignancy risk indices in the detection of malignant ovarian masses. Journal of Gynecologic Oncology 22(3): 177-82.

Bailey, J., Tailor, A., Naik, R., Lopes, A., Godfrey, K., Hatem, H.M., et al. 2006. Risk of malignancy index for referral of ovarian cancer cases to a tertiary center: does it identify the correct cases?. International journal of gynecological cancer: official journal of the International Gynecological Cancer Society 16 Suppl 1:30-4.

Bast, R.C. 2010. Biomarkers for ovarian cancer: new technologies and targets to address persistently unmet needs. Cancer biomarkers: section of a disease markers 8(4-5): 161-6. 
Cohen, J.G., White, M., Cruz, A., Farias-Eisner, R. 2014. Can we do better than CA125 in the early detection of ovarian cancer?. World Journal of Biological Chemistry 5(3): 286-300.

Erondu, C.O., Alberg, A.J., Bandera, E.V., Barnholtz-Sloan, J., Bondy, M., Cote, M.L., et al. 2016. The association between body mass index and presenting symptoms in African American women with ovarian cancer. Journal of Women's Health 25(6): 571-8.

Field, A. 2013. Discovering statistics using IBM SPSS statistics Edisi ke ke-4. London. Sage.

Howlader, N., Noone, A., Krapcho, M., Garshell, J., Neyman, N., Altekruse, S., et al. 2014. SEER Cancer Statistics Review, 1975-2011. National Cancer Institute Bethesda, MD.

Jacobs, I.J. and Menon, U. 2004. Progress and challenges in screening for early detection of ovarian cancer. Molecular \& cellular proteomics: MCP 3(4): 355-66.

Lan, Z., Fu, D., Yu, X., Xi, M. 2016. Diagnostic values of osteopontin combined with CA125 for ovarian cancer: a meta-analysis. Familial Cancer 15(2): 221-30.

Manegold-Brauer, G., Buechel, J., Knipprath-Meszaros, A., Schoetzau, A., Hacker, N.F., Tercanli, S., et al. 2016. Improved detection rate of ovarian cancer using a 2-step triage model of the risk of malignancy index and expert sonography in an outpatient screening setting. International Journal of Gynecology Cancer 26(6): 1062-9.

McIntosh, M.W., Drescher, C., Karlan, B., Scholler, N., Urban, N., Hellstrom, K.E., et al. 2004. Combining CA 125 and SMR serum markers for diagnosis and early detection of ovarian carcinoma. Gynecologic oncology 95(1): 9-15

Moss, E.L., Hollingworth, J. and Reynolds, T.M. 2005. The role of CA125 in clinical practice. J Clin Pathol 58(3): 308-12.

Nakae, M., Iwamoto, I., Fujino, T., Maehata, Y., Togami, S., Yoshinaga, M., et al. 2006. Preoperative plasma osteopontin level as a biomarker complementary to carbohydrate antigen 125 in predicting ovarian cancer. The journal of obstetrics and gynaecology research 32(3): 309-14.

Sarojini, S., Tamir, A., Lim, H., Li, S., Zhang, S., Goy, A., et al. 2012. Early detection biomarkers for ovarian cancer. J Oncol : 709049.

Ong, C., Biswas, A., Choolani, M., Low, J.J. 2013. Comparison of risk of malignancy indices in evaluating ovarian masses in a Southeast Asian population. Singapore medical journal 54(3): 136-9.

Rein, B.J., Gupta, S., Dada, R., Safi, J., Michener, C., Agarwal, A. 2011. Potential markers for detection and monitoring of ovarian cancer. J Oncol : 475983.

Siegel, R., Ma, J., Zou, Z., Jemal, A. 2014. Cancer statistics CA: a cancer journal for clinicians 64(1): 929.

Skates, S.J., Mai, P., Horick, N.K., Piedmonte, M., Drescher, C.W., Isaacs, C., et al. 2011. Large prospective study of ovarian cancer screening in high-risk women: CA125 cut-point defined by menopausal status. Cancer prevention research 4(9): 1401-8. 
Van den Akker, P.A., Aalders, A.L., Snijders, M.P., Kluivers, K.B., Samlal, R.A., Vollebergh, J.H., et al. 2010. Evaluation of the risk of malignancy index in daily clinical management of adnexal masses. Gynecologic oncology 116(3): 384-8.

World Health Organization. 2012. GLOBOCAN 2012: estimated cancer incidence, mortality and pravalence wordwide in 2012. Available from: URL http://globocan.iarc.fr/ Diakses tanggal 1 Januari 2016.

Yamamoto, Y., Yamada, R., Oguri, H., Maeda, N., Fukaya, T. 2009. Comparison of four malignancy riskindices in the preoperative evaluation of patients with pelvic masses. European journal of obstetrics, gynecology, and reproductive biology 144(2): 163-7. 